\title{
Relationship Between Problems And Needs of Extension Workers: A Case Study of Maigana And Samaru Zones of Kaduna State Agricultural Development Project, Nigeria
}

\author{
Jamagani, Z. B. \\ Agricultural Consultant, NO. 11 Idris Gidado Road Hanwa GRA Zaria, Kaduna State Nigeria
}

\begin{abstract}
This study examines the training needs of extension workers of Kaduna State Agricultural Development Project (KADP). For purpose of in-depth analysis, two (2) zones of KADP:-Maigana from the north and Samaru from the southern part were selected for the study. Data for the study were collected through the use of structured questionnaire involving a population of sixty one (61) respondents all agricultural extension workers selected through simple random sampling. The descriptive statistics and correlation analysis were employed in analyzing the data. The finding shows that, there is training needs for extension workers in the area of, developing community group was the most desired training needs with 30.6\%, while crop protection, training for potential workers with 20.8\%, $12.5 \%$ respectively; weed control and subject matter specialist on cassava production with $2.8 \%$ each and $1.4 \%$ represent less training needs. Lack of funding was found to be the major constraint with $45.2 \%$. About $64 \%$ of the extension workers rated their performance as very useful and $32.8 \%$ are rated useful. Pearson correlation analysis revealed that constraints and needs were positive and statistically significant at 0.01 and 0.05 levels. Thus, it is recommended that extension workers should be encouraged to attend seminars, conference, and additional courses in higher institutions. And their welfare needs such as regular promotions so as to motivate them to work more effectively, and there should be enough funding for continuous in-service training.
\end{abstract}

Key Words: Problems, Needs, Extension workers

\section{Introduction}

Nigeria is one of the largest countries in Africa, with a total geographical area of 9, 237, 68 square kilometers and a population of 140 million (NPC, 2006). It is situated within the tropics along the Gulf of Guinea on the West Coast of Africa (Manyong et al., 2006).

The structure of Nigerian agriculture has been characterized historically by the large number of relative small scale family operation farms that account for about $80 \%$ of the total food population (Awoyemi, 1981; Ajakaiye, 1984; Mendelsolen, 2010), with the petroleum exploration in the sixties agricultural development was relegated to the background which has now resulted to an increase level of poverty and food insecurity that leads to a low level of capacity to satisfy the food and fiber needs of the country's production (Oyatoye, 1981; F.A.O., 2001)). One of the most effective means of transforming Nigerians agricultural resources to sustained agricultural development is through an effective extension system. Improved agricultural extension management system is recognized as a central mechanism to achieving increase food production through technology transfer (F. A. O. 2001).

Despite Nigeria's rich agricultural resource endowment, however, the agricultural sector has been growing at a very low rate. Less than $50 \%$ of the Country's cultivable agricultural land is under cultivation. Even then, small holder and traditional farmers are constrained by many problems (Manyong et al., 2006) for any extension organization to improve its performance a continuous and systematic training of its staff is necessary (F. A. O. 2001).

Matmor (1995), Improving the image of extension staff, who should be known for offering information, not only technology, considering also, is how to connect an extension worker with crop protection with regard to the extension part of it.

Almost every developing country now has some sort of organized agricultural extension service; some have several. These extension services vary considerably. Many operate on a nationwide scale, where as others concentrate on a particular geographic area within a country Tukur (1994) most of the developing countries do not have effective extension services due to the fact that training of extension staff is usually inadequate and outdated. for instance, observed that - most training efforts are concentrated on pre-service training, agricultural extension services aimed at assisting families to improve their living standard through increase agricultural production (Benor and Harrison, 1977; 2001).

The extension agents' job was to convince farmers of the potentials of the new technology. Communities and the networks to which people belong play a more important role in influencing agricultural 
practices. Farmer- to- farmer extension is premised on the belief that for a farmer, "seeing is believing" and other are the best educators. Through discussions with other farmers and groups, they will be stimulated to try our new technologies (Ellis- Jones et al., 2005). A continued wide spread improvement in agricultural requires a professional and effective extension service delivery (Androuhdkis and Siardos, 2005).

\section{Area of Study}

Kaduna State occupies part of the central position of Northern Nigeria (with Kaduna as its Capital). It is situated in the North-Western region of Nigeria and shares borders with Katsina, Kano, Niger, and Plateau States. To the South-West, the State shares a border with the Federal Capital Territory, Abuja. The global location of the State is between Longitude 30" east of the Greenwich Meridian and also between Latitude 090 00 " and 11030 " North of the equator. The State occupies an area of approximately 48,473.2 square kilometers and has a population of more than 6 million (NPC, 2006).

There are two major seasons in the state, the Dry Windy season and the rainy (wet) seasons. The wet season usually starts from April through October with great variations as you move North-ward. On the average, the state enjoys a rainy season of about five to six months. There is heavy rainfall in the southern part of the state like Kafanchan and northern part like Zaria with an average rainfall of about $1016 \mathrm{~mm}$.

The State extends from the tropical grassland known as Guinea Savannah to the Sudan in the north. The grassland is a vast region covering the southern part of the State to about latitude 1100" North of the equator. The prevailing vegetation of tall grass and big trees are of economic importance during both the wet and the dry season.

This study was carried out in the two most popular Zones of Kaduna State Agricultural Development Project (KADP) in terms of population and land size.

These are: Maigana and Samaru, these zones fall into two separate agro - ecological Zones of the State.

The Selection of Maigana and Samaru Zones for the study was purposive.

The Zones are picked out of the existing four Zones of the Kaduna State Agricultural Development Project (KADP) based on its accessibility.

\section{Maigana Zone}

Maigana Zone, lies within the Northern Guinea Savanna Zone of Nigeria where weather conditions are characterized by seasonal variations with the rains commencing around May and ending sometimes in October, and dry season commencing around November and ending April. The annual rainfall in this area ranges between $750-1100 \mathrm{~mm}$ per annum, the area has a typical continental type of climate, with a wide temperature range, sometimes (up to 120c) (Jamagani,1998).

Maigana Zone cuts across eight local Government Areas namely: Soba, Giwa, Kubau, Ikara, Makarfi, Kudan, Sabon Gari, and Zaria.

\section{Samaru Zone}

Samaru Zone, lies within the southern Guinea savanna Zones of Nigeria where the climate of the area is generally characterized by wet and dry seasons. The monthly average temperature ranges between $200 \mathrm{c}$ and $320 \mathrm{c}$.

Thus, the rains begin around April and end in October. The annual rainfall ranges from 1,399mm to $1,655 \mathrm{~mm}$ falling over a period of between 130 to 150 days.

The month July, August and September records the highest amount of rainfall Akpoko (1988). Samaru Zone cuts across seven Local Government Areas namely: Jama'a, Jaba, Kachia, Kaura, Kagarko, Sanga and Zango Kataf.

Farming is the major occupation of the people. The traditional economy is characterized by a low population and low farm incomes. The farming system practices are similar throughout the study areas because of cultural similarities among people. The major food crops grown in the area include: sorghum, millet, maize, yam, cocoyam, Sweet-potatoes, cassava, soybeans, cowpea, and vegetables, such as tomatoes, onions, pepper, okra, and amaranch. Among others, and most of these crops are grown for daily subsistence.

\section{Sampling Procedures}

The choice of Maigana and Samaru out of the existing four zones of Kaduna State Agricultural Development Project for this study was purposive due to their accessibility. The extension workers were first identified with the aid of their respective Zonal Managers and Extension Officers after which a total of 97 (100\%) extension workers were identified $42(43.29 \%)$ from Maigana and 55 (56.70\%) from Samaru zones. In all, a total of $61(63 \%)$ respondents were selected using random sampling technique. Of these 61 respondents, 21 respondents (34.4\%) were from Maigana zone and 40 respondents (65.6\%) from Samaru zones. 


\title{
Sources of Data
}

The data for this study were derived from both primary and secondary sources. The data needs were identified on the basis of the objectives of the study. Each data source and method of collection adopted is explained as follows: The secondary data for this study were obtained from records and journals which constituted the major source of the secondary data.

\section{Methods of Data collection}

The primary data were collected with the aid of survey instruments designed for extension workers in agriculture. The instrument dwelt extensively on the perception of the respondents on training needs of agricultural extension workers, the pattern of flow on the training needs, training opportunities available for extension workers, the major constraints hindering the training needs of the extension workers.

The method employed for the field survey was the individual completion of the questionnaire which involved leaving the questionnaire with the individual respondents (on request) to be completed at their convenience and be returned to their respective zonal managers.

\section{Methods of Data Analyses}

The data collected from the primary source were analyzed using simple descriptive and correlation analyses. This involves the use of frequency and percentage to achieved objective 1 and 2 of this study. The Pearson Product Moment Correlation (PPMC) was thus employed to achieve objectives 3 and 4 of the study, i.e. to see the relationship between the dependent variable training needs to the independent variable constraints associated with training needs as identified in the analysis.

Thus, product moment correlation coefficient model ( $\mathrm{r}$ ), training needs of extension workers (x), constraints associated with training needs of the extension worker (y) and number of sample (n).

\section{Mathematical Expression:}

\author{
$r=\frac{n \sum x y-\sum x \sum y}{\sqrt{n} \sum x^{2}-\left(\sum x\right)^{2} \sqrt{ } \sum y^{2}-\left(\sum y\right)^{2}}$ \\ Where:

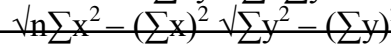 \\ $r=$ Correlation coefficient \\ $\mathrm{n}=$ Number of samples (extension workers) \\ $\mathrm{x}=$ Training needs of extension workers \\ $y=$ Major problems of training needs of the extension workers
}

The expected relationship between the dependent variable and its determinants are as follows. Both $\mathrm{x}$ and $\mathrm{y}$ can have either a positive or a negative relationship.

\section{Result And Discussion}

Respondents expectation after Training

The motivation effect of training opportunities have obvious rational basis that some extension workers articulated in their responses. This study reveals that about $51 \%$ of respondents' expectations after training is to be moved to relevant and equivalent positions of the training received; and $14.8 \%$ wanted senior positions; while some of the respondents wanted promotion to the next rank; and only $1.6 \%$ of the respondents were not sure of what they wanted after the training. About $30 \%$ of the respondents could not respond to the question as revealed on Table 1, probably because they are okay with their present positions.

It is fundamental fact that, every worker needs to be promoted as long as he is qualified. Promotion can come in many forms, through elevation to the next rank or senior position after adding to his/her educational qualification. This can be certificate, diploma or degree. A staff can also be promoted when he has attended a given number of years in service who must have received some training within that period which can warrant his promotion. Another form of promotion is by increasing the salary of the staff whose contribution to the organization is noticed and the only way to boost his morale is by monetary increment. In this case, there is always a high expectation by way of job performance from the employers. 
Table 1: Distribution of Respondents by Expectation after Training

$\begin{array}{lll}\text { Expectation after training } & \text { Frequency } & \\ \text { Promotion beyond the former position } & 2 \\ \text { Move to another senior vacant office available } & 9 \\ \text { Relevant position to the training received } & 31 \\ \text { Others } & 1 & \\ \text { Total } & \mathbf{4 3} & \\ \text { Indifferent Response } & 18 & \\ \text { TOTAL } & \mathbf{6 1} & \\ \text { Extension Workers in the Area of Usefulness } & & \\ \text { Workers usefulness } & \text { Frequency } & 63.9 \\ \text { Very useful } & 39 & 32.8 \\ \text { Useful } & 20 & 3.3 \\ \text { Indifferent } & 2 & \mathbf{1 0 0 . 0} \\ \text { TOTAL } & \mathbf{6 1} & \\ \text { Scates } & & \end{array}$

Scales $1=$ Very useful; $2=$ useful; $3=$ indifferent

Respondents Availability of Training Opportunities

$\begin{array}{lcl}\text { Training Opportunities } & \text { Frequency } & \text { \% } \\ \text { Yes } & 18 & 29.5 \\ \text { No } & 42 & 68.9 \\ \text { Total } & 60 & 98.4 \\ \text { No Response } & 1 & 1.6 \\ \text { TOTAL } & \mathbf{6 1} & \mathbf{1 0 0 . 0}\end{array}$

Major Problem's of Training Needs by Extension Workers

Problems

No encouragement from management

Lack of funding

Lack of adequate working materials

Time constraints

Political and financial sentiment in selection

Lack manpower for supervision

Lack of resource person with special Knowledge

Long distance to training centers

Ineffective promotion criteria after training

Lack of incentives for extension specialist

No support for extension by the government

Irregular programs

TOTAL

Source: Field survey, 2006

\section{Rating of Extension Workers by Usefulness}

Extension workers were asked to "evaluate or rate their usefulness as extension workers". Findings on this were analyzed and presented in Table 2 . Three options were identified.

Most of the respondents 39 (63.9\%) answered "very useful" and 20 (32.8\%) answered "useful", while 2 (3.3\%) were "indifferent". These two options of useful and very useful giving a total of $96.7 \%$ appeared to dominate the extension workers usefulness in their areas of responsibilities. This finding therefore, contrasts a similar finding of Cho and Herman (2003).

In every working organization there is the need for general staff evaluation in order to give way for the person in question to improve on the challenges that are seen to be weaknesses on the part of the worker. In well established organizations, subordinates are asked by their supervisors to evaluate themselves before the final evaluation by supervisor. Staff evaluation is an antidote for encouraging the workers to take their work more seriously instead of showing unconcern attitudes to their job.

\section{Respondents Training Opportunities}

This study shows that more than half of the extension workers who responded $(68.8 \%)$ had not had the opportunity of enjoying any training that will improve their skills (Table 3). This contrasts the study of Daniel and Harrison (1977) that training of extension staff is usually inadequate. 
About $69 \%$ of the respondents had not had the opportunity of receiving or going outside for a training even once. Only $29.5 \%$ of the respondents had enjoyed the training opportunity once or more while $1.6 \%$ could not suggest either of the options the reasons could be that he/she is a newly employed staff, or he/she had not made an attempt to go and add to his/her skills.

In order to be an effective extension worker who wants to impart knowledge to farmers, there is need to encourage the extension workers by giving them the opportunity to go to institutions of learning or training centers in order to improve on their skills and knowledge on how to disseminate information on new techniques to farmers who are always the targeted people of the extension worker.

Thus, looking at Table 3, it could be observed that less than $30 \%$ of the respondents had training opportunity against the remaining $70 \%$ who had not had the opportunity to received training in extension to improve their working skills on the field.

\section{Problems of Training Needs by Extension Workers}

Although, there were differences in order of importance of the problems as identified by the extension workers, the major problems hindering the trainings as found out in this study were; Lack of fund with about $45.2 \%$. Other constraints included: lack of government encouragement (16.1\%), lack of adequate working materials $(13.7 \%)$, lack of resource person with specialist knowledge and time constraints $(2.4 \%)$, in-effective promotion criteria after training and lack of incentive for specialist (1.6\% each), and political and financial sentiment on selection, long distance to training centers and irregular programmers' (0.8\% each), see Table 4. The study that collaborated this finding include that of Fremy (1995).

If we can take a look at the major problems facing the extension training needs in the ADPs, there is a need to address these properly. There can never be a good and Vibrant Extension worker if the problem of training is not taken care of. The first three and most pressing problems among others are lack of funding, lack of encouragement by government, and inadequate working materials.

Holistically, training will continue to have these problems. There is need for the appropriate quarters to address the issues of funding and the other problems. Funding should be made readily available to train and have skill extension workers in Nigeria.

\section{Relationship between problems and Needs of Extension Workers}

The correlation analysis results show that, there is a significant interrelationship at the 0.01 level (2tailed) between: training on monitoring and developing community groups; how to conduct surveys and specialist on maize and cassava production. Also, the correlation is significant at the 0.05 level (2-tailed) between: training on weeds control and training human development; training method and presentation skills and induction training for potential workers.

In addition to this, it is observed that, at the 0.01 level, the correlation is significant between working materials and developing community groups, then at 0.05 levels, the correlation is significant between working materials and how to conduct field demonstration, this is indicated in Table 5. 
Table 2: Relationship between Problems and Needs on Training of the respondents

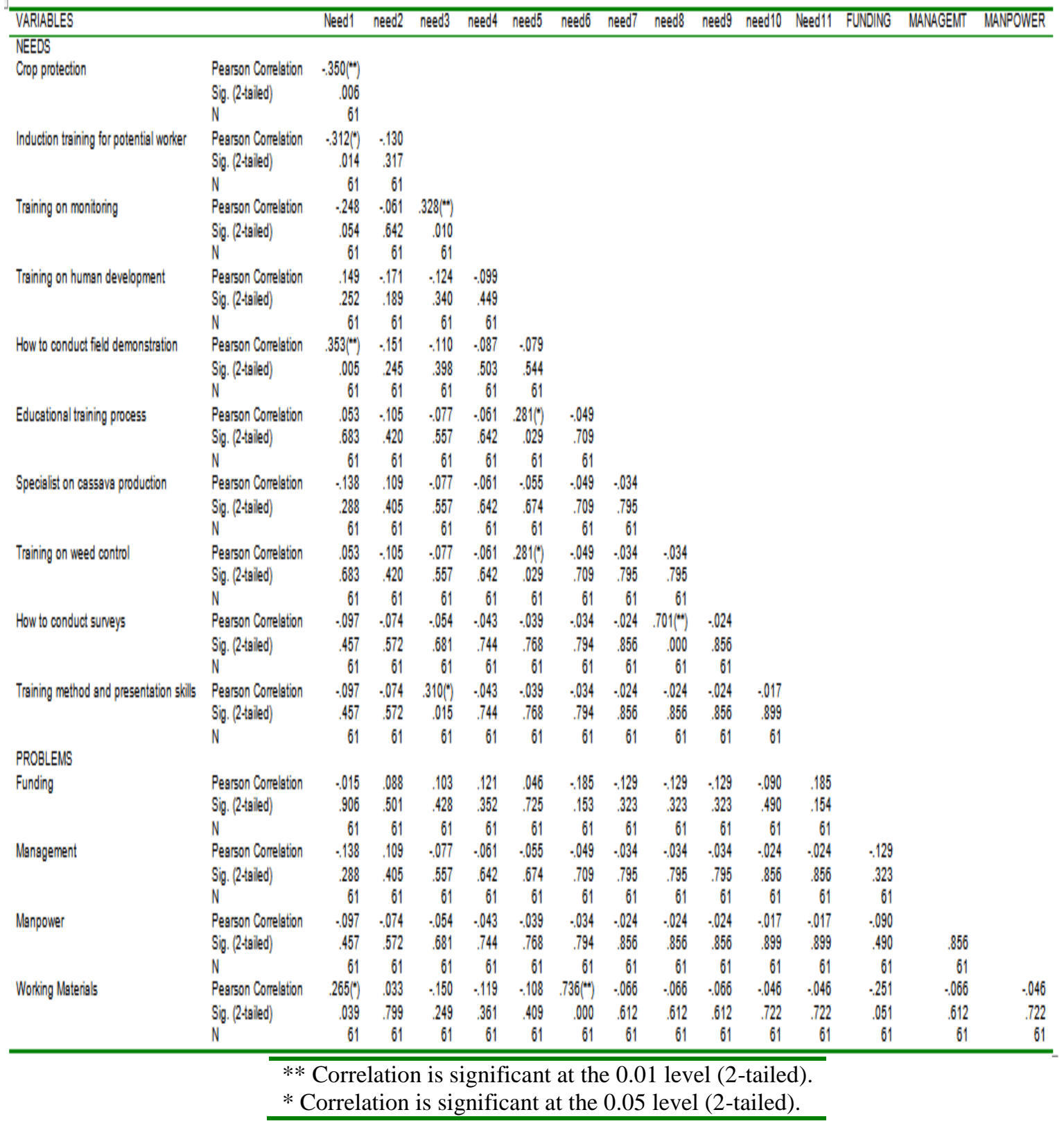

\section{Conclusion}

From the finding of this study, it can be deduced that the extension workers of the Maigana and Samaru zones of Kaduna State Agricultural Development Project (KADP) are still and truly in need of training. This training should be obtained for qualification, which means that extension workers should be made to obtain higher qualification like degrees, in agriculture and other agricultural related fields of interest. This will give them a broader view of extension work and also of what they have to deal with as extension workers in any way.

\section{Recommendations}

Based on the following recommendations were made

1. There should be constant training for extension workers which can be inform of seminars, workshops, conferences etc that can be inform of various aspects in agriculture, since it will aid in expanding their abilities to relate more comprehensively with both farmers families and the community in which they find themselves. However, training for extension workers remain an essential factor for meeting up with the trends and drive for effectiveness.

2. The Federal and State Government along side with Non-Governmental organizations should encouraged the extension workers by proving funds to enable them engaged in in-services within and outside Nigeria. 
3. Allow the extension workers promotion to flow automatically once they attend the required qualification and years of services as a way of motivating their welfare.

\section{References}

[1]. Akpoko, J. G. (1988). Socio-economic constraints on Agricultural Production in Jema'a Local Government Area of Kaduna State. (M.Sc Thesis), Ahmadu Bello University Zaria (1988), P76

[2]. Ajakaiye, M.B. (1984). The private Sector and Nigerian Agricultural Development. Agriculture and Rural Management Training institute, Ilorin, Nigeria, 250pp.

[3]. Androuhdkis, S. I., and Siardos, G. C. (2005). Agricultural extension agent's Perception regarding their relevance and competence in certain professional task area. $114 \mathrm{p}$. Availabl at www.Jimmyproject.org

[4]. Awoyemi, O.(1981). Problems of Agriculture in Nigeria pp37-49. In: - Ojo, M.O; Edordu, C.C.; and Akingbade, J.A. eds) Agricultural Credit Finance in Nigeria: Problems and prospects. Proceedings of a seminar organized by the Central Bank of Nigeria, April $27-30,1981$ at the University of Ibadan, Nigeria, 659 pp.

[5]. Benor, D. and Harrison, J. (2006). Funding, training and visit extension, extension approach. Journal of International Agricultural and extension Education 4(1); 9 - 12.

[6]. Benor, Daniel; and Harrison, Q.James (1977). Agricultural Extension. The Training and Vision System. World Bank, Washington, D.C; 20433, USA, pp $6-7$

[7]. Cho, K. M. and Hermann B. (2003). Technological and Institutional Innovations for sustainable Rural Development Towards a sustainable Development in Agriculture: An Analysis of Training Needs for Potential Extension Agents in Myanmar.Deutscher Tropentag, October 8-10, 2003 in Gottingen(International Research on Food Security, Natural Resource Management and Rural Development), PP1-8.

[8]. Ellis-Jones, J., S. Schulz, D. Chikoye, N. deHaan, P. Kormawa, and D. Adedzwa. (2005). Participatory research and extension approaches: guide for researchers and extension workers for involving farmers in research and development. International Institute of Tropical Agriculture, Ibadan, Nigeria and Silsoe Research Institute, UK, 52p

[9]. FAO, (2001). Global consultation on agricultural extension services. A Journal of extension Education 2 (3); 11 - 14

[10]. Fremy, J. (1995). Human Resources Development and Management Issue: In service Training Needs and challenges. In: Cassaday, K.A., G. Monnet and C.R. Downswell (eds). Strengthening National Extension Service in Sub - Sahara African. Mexico, D.F: CASIN/SSA/GLOBAL 2000.

[11]. Manyong V. M., A. D. Alene, D. Sanogo, O. Coulibaly, S. Abele, and G. B. Nkamleu. (2006). Achievements in impact assessment of agricultural research: IITA's experience, 2001-2007 impact series, International Institute of Tropical Agriculture, Ibadan, Nigeria. PP 73 Mendelsolen J. (2010). Farming Systems in Namibia. Windhoek, Namibia: NNFU

[12]. Matmor, Z. (1995). Extension Linkages with Research, Production, and Credit Institutions. In: - Cassaday, K. A., G. Monnet. Eds. (1995). Strengthening National Extension Services in Sub-Saharan Africa. Mexico, D.F.:CASIN/SSA/Global 2000, pp.25-26

[13]. National Population Commission NPC (2006), Federal Republic of Nigeria, Abuja.

[14]. Oyatoye, E. T. O. (1981). Nigerian Agriculture: Problems and Prospect. In: - ojo, M.O.; Edordu, C.C.; and Akingbade, J.A. eds. Agricultural Credit and Finance in Nigeria: Problems and Prospects. Proceedings of a seminar organized by the Central Bank of Nigeria, April 27-30, 1981 at the University of Ibadan, Nigeria, 659pp.

[15]. Tukur, S. B. (1994). Kano State Agricultural and Rural Development Authority, Nigeria. In: - Cassaday, K. A., G. Monnet and C. R. Dowswell, eds. 1994. Strengthening National Extension Services in Sub-Saharan Africa. Mexico, D. F.: CASIN/SSA/Global 2000, pp. 64-65. 